\title{
Effect of Latamoxef on Platelet Function and Prothrombin Time in Partially Nephrectomized Rats
}

\author{
Kiyohisa UCHIDA, Masuhisa NAKAMURA, Masaharu KONISHI, \\ Toyokazu ISHIGAMI and Taichiro KOMENO
}

Shionogi Research Laboratories, Shionogi \& Co., Ltd.,

Fukushima-ku, Osaka 553, Japan

Accepted September 16, 1986

\begin{abstract}
Latamoxef (daily 100 and $300 \mathrm{mg} / \mathrm{kg}$, i.v.) was injected once a day for 8 days to $75 \%$ and $90 \%$ nephrectomized rats kept on a vitamin $\mathrm{K}$-sufficient diet (500-600 ng/g) or a vitamin K-deficient diet (30-50 ng/g), and changes in ADP. induced platelet aggregation and prothrombin time were examined. The half-life of latamoxef was markedly prolonged and plasma latamoxef and $N$-methyltetrazolethiol (NMTT) concentrations increased, resulting in a delay of the total body clearance of the compounds. The ADP-induced platelet aggregation increased after nephrectomy, and latamoxef slightly but inconsistently decreased the aggregation. Prothrombin time did not change even in the $90 \%$ nephrectomized rats kept on an ordinary diet, but increased dose-dependently in the vitamin K-deficient nephrectomized rats, with the $90 \%$ nephrectomized animals showing larger increases of prothrombin time. These data suggest that NMTT or NMTT-containing antibiotics cause no hypoprothrombinemia even in partially nephrectomized rats when they are fed an ordinary diet containing vitamin $K$, but these compounds enhance the manifestation of hypoprothrombinemia in vitamin $\mathrm{K}$ deficiency. Further renal failure promotes the manifestation by increasing drug concentration in the blood. However, platelet aggregation in these animals is not significantly affected at the doses examined.
\end{abstract}

Renal failure is considered to enhance the manifestation of side-effects of drugs by prolonging high drug levels in the blood. In the case of antibiotics, renal dysfunction is a risk factor for developing coagulopathy (1-3).

Recently, latamoxef (moxalactam) has been reported to decrease ADP-induced platelet aggregation (4) and produce hypoprothrombinemia in vitamin K-deficient patients $(5,6)$ and experimental animals $(7$. 8). The hypoprothrombinemia is produced not only by latamoxef but also by the other antibiotics which possess $N$-methyltetrazolethiol (9-15) or methylthiadiazolethiol (16) in their structures, since such sidechains interfere with the reuse of vitamin $K$ by inhibiting vitamin $K$-epoxide reductase (17).

In the present experiment, we examined the effect of latamoxef on ADP-induced platelet aggregation and prothrombin time in partially nephrectomized rats which show markedly decreased glomeruler filtration rate (GFR) (18) and creatinine clearance (19).

\section{Materials and Methods}

Sprague-Dawley male rats, 8 weeks old, obtained from Japan Clea were kept in an air-conditioned room $\left(25 \pm 1^{\circ} \mathrm{C}, \quad 50-60 \%\right.$ humidity) lighted $12 \mathrm{hr}$ a day ( 8 a.m. to 8 p.m.). Commercially available diet (JCLCA-1, Japan Clea Co., Ltd., Tokyo) was used as a vitamin $\mathrm{K}$-sufficient diet containing $500-600 \mathrm{ng} / \mathrm{g}$ of vitamin $K_{1}$. A vitamin $\mathrm{K}$ deficient diet containing 30-50 $\mathrm{ng} / \mathrm{g}$ of vitamin $K_{1}$ was prepared with vitamin $K$ free casein $(18.0 \%)$, sucrose $(67.6 \%)$, a mixture of rapeseed and soybean oils (8.0\%). salt mixture (Hegsted salt) $(4.0 \%)$, fibers $(1.5 \%)$ and adequate amounts of vitamins 
except vitamin $\mathrm{K}$.

Partial nephrectomy of the rats was performed by the method of Ormrod and Miller (18). Briefly, about 50\% (or $80 \%$ ) of the tissue weight of one kidney was cut off using a razor blade under sodium methylhexabital anesthesia $(125 \mathrm{mg} / \mathrm{kg}$, i.p.) and one week after the operation, the contralateral kidney was removed under anesthesia to obtain a $75 \%$ (or 90\%) nephrectomized animal. Latamoxef was injected i.v. once a day at $100 \mathrm{mg} / \mathrm{kg}$ or $300 \mathrm{mg} / \mathrm{kg}$ for 8 days at 3 weeks after the second operation for the $75 \%$ nephrectomized rats, and after 2 weeks for the $90 \%$ nephrectomized rats. At $3 \mathrm{hr}$ after the last injection, the animal was placed under sodium methylhexabital anesthesia (125 $\mathrm{mg} / \mathrm{kg}$. i.p.), and blood was withdrawn from the abdominal aorta with a disposable syringe containing $1 / 10$ volume of $3.8 \%$ sodium citrate solution.

Plasma and urine creatinine levels were determined and creatinine clearance was calculated (19). Plasma urea-nitrogen. albumin and total protein levels were determined by the Technicon Auto Analyzer SMA PLUS MICRO (New York), and ureanitrogen clearance was estimated in a similar manner.

Plasma latamoxef and NMTT levels were determined using a high performance liquid chromatograph (HPLC) with a Varian liquid chromatograph Model LC-5000 equipped with a stainless steel column, $15 \mathrm{~cm} \times 6.0$ $\mathrm{mm}$ I.D., packed with YMC A-312 $(5 \mathrm{~km})$ octadecylsilane reverse phase (Yamamura Chemical Laboratory Corp., Kyoto), and a
Model 100 UV detector (at $254 \mathrm{~nm}$ wavelength). A Rheodyne 7125 loop injector was used with a 500- $u$ l sample loop. All chromatograms were recorded and calculated with a Shimadzu C-R2AX data processer. The mobile phase was prepared by mixing $250 \mathrm{ml}$ of methanol with $750 \mathrm{ml}$ of phosphate buffer ( $\mathrm{pH}$ 6.0, ionic strength $0.075 \mathrm{M}$ ) containing $5 \mathrm{mM}$ of tetrabutylammonium hydroxide. The solvent flow rate was 1.0 $\mathrm{m} l / \mathrm{min}$. The detection limits were $2 \mathrm{~kg} / \mathrm{ml}$ of rat plasma or latamoxef and $0.5 \mu \mathrm{g} / \mathrm{ml}$ for NMTT.

Platelet aggregation was examined by the method of Born (20) using a Type AUTORAM 61 aggregometer (Rika-Denki Co., Ltd., Tokyo). Prothrombin time was determined with a CLOTEK apparatus (Hyland Division Travenol Laboratories, Inc., Costa Mesa, California). Adenosine diphosphate (ADP) was obtained from P-L Biochemical Inc. (Milwaukee) and latamoxef (disodium salt) from Shionogi \& Co., Ltd. (Osaka).

\section{Results}

Table 1 shows the creatinine clearance and urea-nitrogen clearance in the partially nephrectomized rats. The creatinine clearance decreased to about $60 \%$ of the control in the $75 \%$ nephrectomized rats and to about $30 \%$ in the $90 \%$ nephrectomized rats. The ureanitrogen clearance decreased respectively to $40-50 \%$ and to $20-30 \%$ in these animals. These values were almost constant regardless of the time after operation.

The plasma creatinine and urea-nitrogen levels increased in the $75 \%$ nephrectomized

Table 1. Creatinine and urea-nitrogen clearances in sham-operated (control) and partially nephrectomized rats

\begin{tabular}{|c|c|c|c|c|c|}
\hline & \multirow{2}{*}{ Groups } & \multicolumn{3}{|c|}{ Weeks after operation } & \multirow[b]{2}{*}{4} \\
\hline & & 1 & 2 & 3 & \\
\hline \multirow{3}{*}{$\begin{array}{l}\text { Creatinine } \\
\text { clearance } \\
(\mathrm{m} / / 100 \mathrm{~g} / 24 \mathrm{hr})\end{array}$} & Control & $663 \pm 29^{\alpha}(100)$ & $777 \pm 37(100)$ & $510 \pm 25(100)$ & $468 \pm 33(100)$ \\
\hline & $75 \%$ Nephrectomy & $397 \pm 18^{*}(60)$ & $441 \pm 25^{*}(57)$ & $274 \pm 20^{*}(54)$ & $281 \pm 23^{*}(60)$ \\
\hline & $90 \%$ Nephrectomy & $228 \pm 14^{*}(34)$ & $214 \pm 15^{*}(28)$ & $148 \pm 18^{*}(29)$ & $138 \pm 20^{*}(30)$ \\
\hline \multirow{3}{*}{$\begin{array}{l}\text { Urea-nitrogen } \\
\text { clearance } \\
(\mathrm{m} ! / 100 \mathrm{~g} / 24 \mathrm{hr})\end{array}$} & Control & $476 \pm 41(100)$ & $466 \pm 36(100)$ & $556 \pm 46(100)$ & $483 \pm 41(100)$ \\
\hline & $75 \%$ Nephrectomy & $230 \pm 14^{*}(48)$ & $260 \pm 17^{*}(56)$ & $219 \pm 14^{*}(40)$ & $215 \pm 18^{*}(44)$ \\
\hline & $90 \%$ Nephrectomy & $153 \pm 11^{*}(32)$ & $140 \pm 9^{*} \quad(30)$ & $107 \pm g^{*} \quad(19)$ & $110 \pm 16^{*}(23)$ \\
\hline
\end{tabular}

\footnotetext{
${ }^{a}$ Mean \pm S.E. in over 5 rats. *Statistically significant compared with the control $(P<0.05)$. ( ) Percen-
} tages of the control. 
Table 2. Plasma creatinine, urea-nitrogen, albumin and total protein levels in partially nephrectomized rats

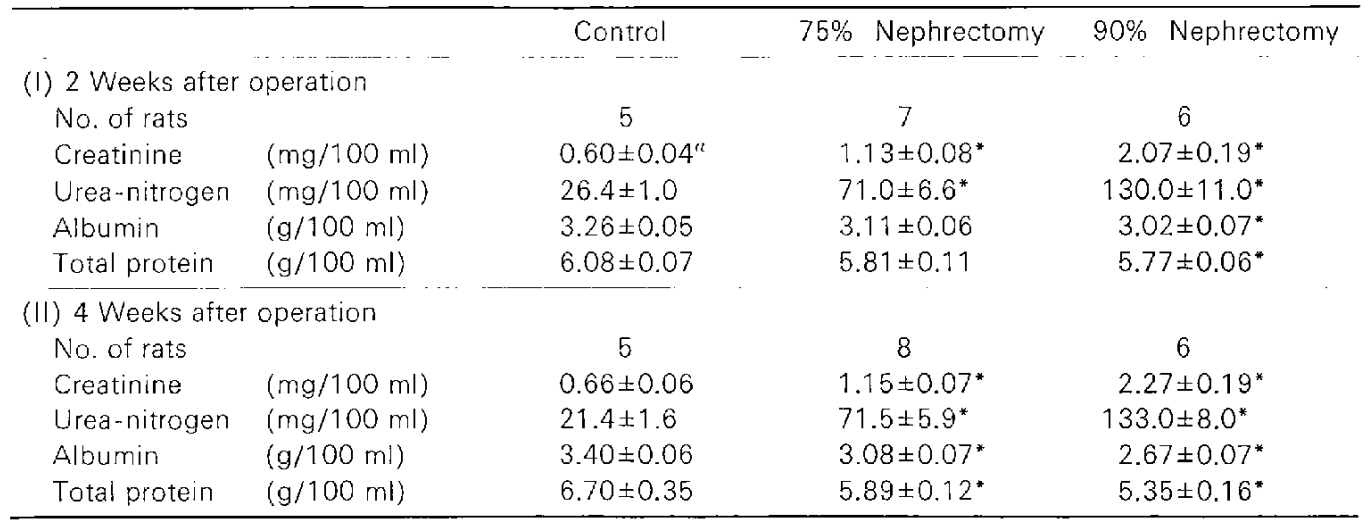

"Mean \pm S.E. * Statistically significant compared with the control $(\mathrm{P}<0.05)$.

Table 3. Changes of ADP-induced platelet aggregation in $75 \%$ nephrectomized rats

\begin{tabular}{ccccccc}
\hline $\begin{array}{c}\text { Weeks after } \\
\text { nephrectomy }\end{array}$ & - & \multicolumn{3}{c}{ Control } & & \multicolumn{3}{c}{ Nephrectomized } \\
& 1 & ADP $(\mu \mathrm{M})$ & & 1 & 3 & 5 \\
3 & $16.5 \pm 3.2^{\prime \prime}$ & $52.6 \pm 1.4$ & $61.1 \pm 1.9$ & $26.0 \pm 4.1^{\prime}$ & $54.4 \pm 4.2$ & $64.5 \pm 2.9$ \\
4 & $21.1 \pm 1.6$ & $55.0 \pm 1.0$ & $64.0 \pm 0.6$ & $43.4 \pm 3.7^{*}$ & $68.7 \pm 1.1^{*}$ & $74.0 \pm 1.0^{*}$ \\
6 & $26.4 \pm 2.1$ & $52.9 \pm 1.1$ & $60.7 \pm 0.5$ & $32.2 \pm 1.7^{*}$ & $58.4 \pm 1.3^{*}$ & $65.2 \pm 1.1$ \\
8 & $13.2 \pm 3.4$ & $47.0 \pm 2.4$ & $56.8 \pm 1.8$ & $27.4 \pm 4.9$ & $57.8 \pm 2.2^{*}$ & $64.2 \pm 1.8^{*}$ \\
\hline
\end{tabular}

"Mean \pm S.E. in 5 rats. Values represent maximal aggregations in percentage. * Statistically significant compared with the paired-control $(P<0.05)$.

rats (Table 2), concomitantly with the decreases of these clearance values (Table 1). The plasma albumin and total protein concentrations also decreased progressively with time in the nephrectomized rats. The maximum decrease in plasma protein concentration was $20 \%$, as shown in Table 2 .

Figure 1 shows the disappearance curves of latamoxef in the control and $90 \%$ nephrectomized rats, when $20 \mathrm{mg} / \mathrm{kg}$ of latamoxef had been injected i.v. The half-life of latamoxef was $17.3 \mathrm{~min}$ in the control rats, but it was 63.2 min in the nephrectomized rats. Thus, the elimination rate constant $K_{10}$ decreased $(0.0368 \mathrm{vs}$. $0.1147 / \mathrm{ml})$. The area under the curve was increased (5.23 vs. 1.54 $\mathrm{mg} \cdot \mathrm{min} / \mathrm{ml}$ ), and the total body clearance was decreased (3.94 vs. $13.15 \mathrm{ml} / \mathrm{min} / \mathrm{kg}$ ) in the nephrectomized rats.

Time course changes in the ADP-induced platelet aggregation are given in Table 3 . $A D P$-induced platelet aggregation was rather

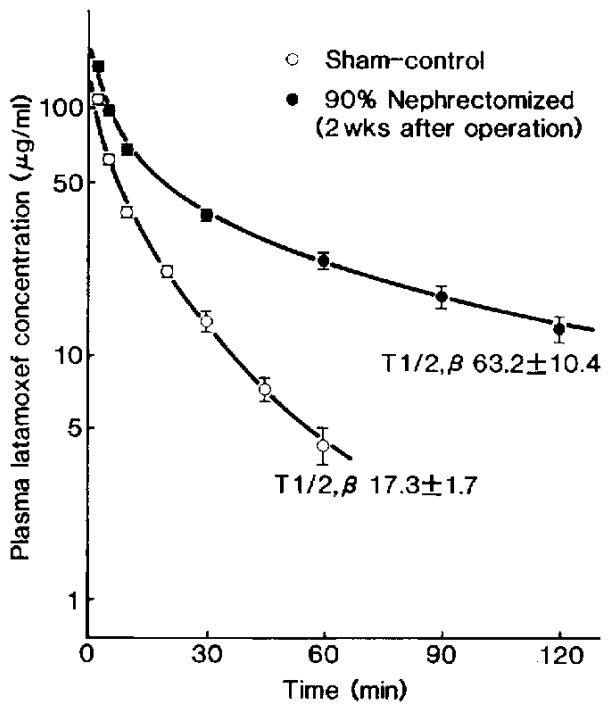

Fig. 1. Plasma latamoxef] concentration in sham operated control and $90 \%$ nephrectomized rats given $20 \mathrm{mg} / \mathrm{kg}$ i.v. of latamoxef. Values and bars represent the mean and S.E. in 6 rats. 
enhanced after nephrectomy. This enhancement, however, was not related to the period after operation.

Table 4 shows the effect of latamoxef treatment on ADP-induced platelet aggregation and prothrombin time in the partially nephrectomized rats kept on an ordinary diet. The platelet aggregation slightly

Table 4. Effect of latamoxef on ADP-induced platelet aggregation and prothrombin time in shamoperated and partially nephrectomized rats (ordinary diet)

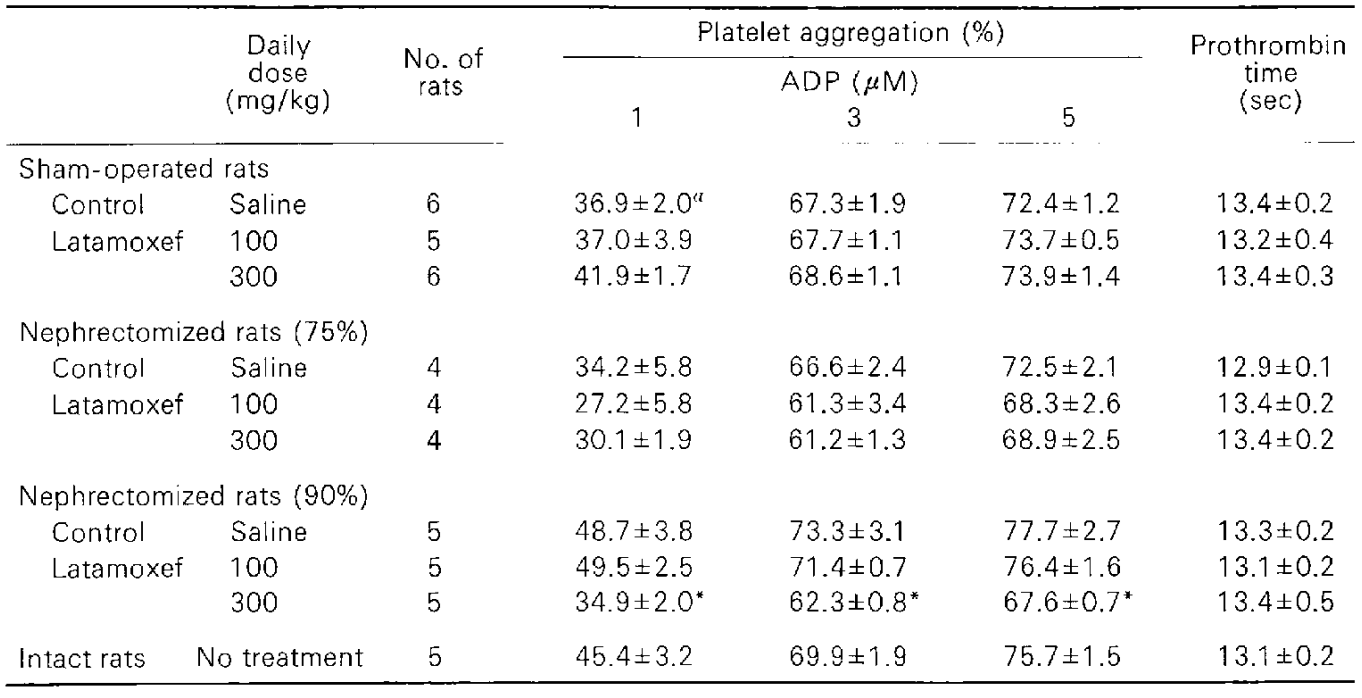

"Mean土S.E. * Statistically significant compared with the control $(P<0.05)$. Latamoxef was injected i.v. once a day for 8 days from the $3 \mathrm{rd}$ week for the $75 \%$ nephrectomized rats and from the 2 nd week for the $90 \%$ nephrectomized rats.

Table 5. Effect of latamoxef on ADP-induced platelet aggregation and prothrombin time in shamoperated and partially nephrectomized rats (vitamin K-deficient diet)

\begin{tabular}{|c|c|c|c|c|c|c|}
\hline & \multirow{3}{*}{$\begin{array}{c}\text { Daily } \\
\text { dose } \\
(\mathrm{mg} / \mathrm{kg})\end{array}$} & \multirow{3}{*}{$\begin{array}{l}\text { No. of } \\
\text { rats }\end{array}$} & \multicolumn{3}{|c|}{ Platelet aggregation (\%) } & \multirow{3}{*}{$\begin{array}{c}\text { Prothrombin } \\
\text { time } \\
\text { (sec) }\end{array}$} \\
\hline & & & & $\operatorname{ADP}(\mu \mathrm{M})$ & & \\
\hline & & & 1 & 3 & 5 & \\
\hline \multicolumn{7}{|c|}{ Sham-operated rats } \\
\hline Control & Saline & 6 & $29.3 \pm 2.2^{a}$ & $56.4 \pm 2.1$ & $64.6 \pm 2.1$ & $13.2 \pm 0.4$ \\
\hline \multirow[t]{2}{*}{ Latamoxef } & 100 & 6 & $23.8 \pm 3.0$ & $55.1 \pm 2.6$ & $65.2 \pm 1.2$ & $13.9 \pm 0.4$ \\
\hline & 300 & 6 & $28.4 \pm 2.2$ & $58.3 \pm 2.6$ & $65.1 \pm 2.5$ & $14.7 \pm 0.6$ \\
\hline \multicolumn{7}{|c|}{ Nephrectomized rats (75\%) } \\
\hline Control & Saline & 5 & $37.1 \pm 1.7$ & $63.5 \pm 1.2$ & $69.7 \pm 1.1$ & $11.8 \pm 0.04$ \\
\hline \multirow[t]{2}{*}{ Latamoxef } & 100 & 5 & $33.0 \pm 2.0$ & $62.8 \pm 1.0$ & $69.7 \pm 0.7$ & $13.5 \pm 0.9$ \\
\hline & 300 & 5 & $16.4 \pm 4.3^{*}$ & $49.9 \pm 4.5^{*}$ & $58.8 \pm 4.1$ & $18.1 \pm 1.5^{*}$ \\
\hline \multicolumn{7}{|c|}{ Nephrectomized rats $(90 \%)$} \\
\hline Control & Saline & 5 & $31.4 \pm 3.0$ & $62.9 \pm 1.9$ & $71.1 \pm 2.4$ & $12.4 \pm 0.4$ \\
\hline \multirow[t]{2}{*}{ Latamoxef } & 100 & 6 & $32.7 \pm 2.2$ & $62.9 \pm 2.0$ & $70.2 \pm 1.3$ & $16.2 \pm 0.7^{*}$ \\
\hline & 300 & 6 & $26.1 \pm 2.2$ & $57.2 \pm 1.6$ & $64.7 \pm 1.3$ & $23.9 \pm 4.4^{*}$ \\
\hline \multicolumn{2}{|c|}{ Intact rats (Ordinary diet) } & 4 & $31.2 \pm 2.8$ & $62.6 \pm 1.1$ & $68.4 \pm 0.9$ & $13.5 \pm 0.4$ \\
\hline
\end{tabular}

${ }^{a}$ Mean \pm S.E. * Statistically significant compared with the control $(P<0.05)$. Latamoxef was injected i.v. once a day for 8 days from the 3 rd week for the $75 \%$ nephrectomized rats and from the 2 nd week for the $90 \%$ nephrectomized rats. 
Table 6. Plasma concentrations of latamoxef and NMTT after i.v. injection of latamoxef to sham-operated and nephrectomized rats

\begin{tabular}{|c|c|c|c|c|}
\hline \multirow[t]{2}{*}{ Diet } & & \multirow{2}{*}{$\begin{array}{c}\text { Daily } \\
\text { dose } \\
(\mathrm{mg} / \mathrm{kg})\end{array}$} & \multicolumn{2}{|c|}{$\begin{array}{l}\text { Plasma concentration } \\
\qquad(\mu \mathrm{g} / \mathrm{ml})\end{array}$} \\
\hline & & & Latamoxef & NMTT \\
\hline \multirow[t]{6}{*}{ Ordinary diet } & Sham-operated & ats & & \\
\hline & Latamoxef & 100 & $<2$ & $1.19 \pm 0.16^{a}$ \\
\hline & & 300 & $<2$ & $1.76 \pm 0.17$ \\
\hline & Nephrectomized & rats $(90 \%)$ & & \\
\hline & Latamoxef & 100 & $54.0 \pm 5.9^{a}$ & $10.8 \pm 1.5$ \\
\hline & & 300 & $222.8 \pm 19.4$ & $36.4 \pm 4.6$ \\
\hline \multirow{6}{*}{$\begin{array}{l}\text { Vitamin K- } \\
\text { deficient diet }\end{array}$} & Sham-operated & ats & & \\
\hline & Latamoxef & 100 & $<1$ & $0.58 \pm 0.04^{a}$ \\
\hline & & 300 & $<1-3.52$ & $1.41 \pm 0.12$ \\
\hline & Nephrectomized & rats $(90 \%)$ & & \\
\hline & Latamoxef & 100 & $45.9 \pm 6.9^{a}$ & $15.4 \pm 1.6$ \\
\hline & & 300 & $191.5 \pm 17.0$ & $33.0 \pm 1.8$ \\
\hline
\end{tabular}

NMTT: N-Methyltetrazolethiol. "Mean \pm S.E. in 5-6 rats.

decreased in the $90 \%$ nephrectomized rats treated with a higher dose of latamoxef, but not in the $75 \%$ nephrectomized rats. On the other hand, prothrombin time was not changed by the treatment with latamoxef even in the $90 \%$ nephrectomized rats. Similar experiments were performed with rats kept on a vitamin $\mathrm{K}$-deficient diet for the last one week (Table 5). The ADP-induced platelet aggregation slightly decreased after the treatment in the $75 \%$ nephrectomized rats but not in the $90 \%$ nephrectomized rats. However, prothrombin time dose-dependently increased after the treatment with latamoxef, and the increase was greater in the $90 \%$ nephrectomized rats.

Table 6 shows the plasma concentrations of latamoxef and NMTT in the animals shown in Tables 4 and 5 . Since the animals were sacrificed $3 \mathrm{hr}$ after the last injection. the plasma latamoxef concentrations were less than $2 \mu \mathrm{g} / \mathrm{ml}$ in all the sham-control rats. However, the concentrations were about 50 $\mu \mathrm{g} / \mathrm{ml}$ and $200 \mu \mathrm{g} / \mathrm{ml}$ in the $90 \%$ nephrectomized rats receiving 100 and $300 \mathrm{mg} / \mathrm{kg}$ of latamoxef, respectively. The plasma NMTT concentrations were also less than $2 \mu \mathrm{g} / \mathrm{ml}$ in the control rats, but they were $10-15 \mu \mathrm{g} / \mathrm{ml}$ and $33-36 \mu \mathrm{g} / \mathrm{ml}$ in the nephrectomized rats, respectively.

\section{Discussion}

The present data demonstrate that latamoxef causes no hypoprothrombinemia even in partially nephrectomized rats when they are fed a regular diet containing sufficient amounts of vitamin $K$, but latamoxef enhances the manifestation of hypoprothrombinemia in vitamin $\mathrm{K}$-deficient rats and renal failure promotes its manifestation, probably by increasing the plasma drug concentration. These data suggest that this latamoxef effect in vitamin $\mathrm{K}$ deficiency can be prevented by vitamin $K$ feeding even in $90 \%$ nephrectomized rats, where creatinine clearance is only $30 \%$ of that in the control animals. The vitamin $\mathrm{K}$-deficient diet which we prepared contained $30-50 \mathrm{ng} / \mathrm{g}$ of vitamin $\mathrm{K}_{1}$, a marginal dose which prevents hypoprothrombinemia in male rats (21). When male rats are fed a diet which contains lesser amounts of the vitamin, marked hypoprothrombinemia manifests itself within a few days (21).

Vitamin $\mathrm{K}$ is absorbed in the quinone form. reduced to the biologically active dihydroquinone form by vitamin $K$ reductase mainly in the liver, converted to vitamin $K$ epoxide coupled with the $r$-glutamylcarboxylation reaction, and then reduced to the original 
quinone form by vitamin $\mathrm{K}$ epoxide reductase (22). This sequence is known as the vitamin $\mathrm{K}$ cycling. Although NMTT or NMTTcontaining antibiotics including latamoxef have been reported to inhibit $\gamma$-glutamylcarboxylation (23), we have previously demonstrated that NMTT or latamoxef does not inhibit $\gamma$-glutamylcarboxylase (24), even under conditions in which prothrombin time is increased and plasma clotting factors such as prothrombin and factor $\mathrm{VH}$ are markedly decreased (21). Recently, Bechtold et al. $(25,26)$ demonstrated that cephalosporins including latamoxef increase plasma vitamin Kepoxide levels, and Suttie and his colleagues $(15,17)$ have proposed that NMTT or NMTTcontaining antibiotics inhibit vitamin $K$ epoxide reductase. These results suggest that NMTT or NMTT-containing antibiotics do not inhibit $\gamma$-glutamylcarboxylase but inhibit vitamin $K$ epoxide reductase, resulting in impairment of the vitamin $\mathrm{K}$ cycling. This hypothesis fits well with many phenomena observed with the use of these antibiotics. since the drug-induced hypoprothrombinemia manifests itself only with vitamin $\mathrm{K}$ deficiency $(3,7,8)$ and is easily overcome by treatment with vitamin $\mathrm{K}(3,8,27,28)$.

The hypoprothrombinemia observed in the vitamin K-deficient and partially nephrectomized rats seems to be due to interruption of the vitamin $\mathrm{K}$ cycling caused by delayed excretion of the drug. The total body clearance of latamoxef in the $90 \%$ nephrectomized rats was markedly decreased (3.94 vs. $13.15 \mathrm{ml} / \mathrm{min} / \mathrm{kg}$ ).

Our data suggest that ADP-induced platelet aggregation increases in the partially nephrectomized rats (Table 3 ). Bang et al. (29) reported that ADP - and collageninduced platelet aggregations are enhanced in patients with nephrosis. This enhancement may be related to the decrease in plasma albumin concentration, since a decrease in binding of arachidonic acid to albumin may increase thromboxane $A_{2}$ synthesis (30). Thus, the observed enhancement of platelet aggregation may be linked to the decreased albumin concentration also observed in our nephrectomized rats. However, platelet function is decreased in advanced uremic patients (31). The increase of platelet ag- gregation in our $75 \%$ nephrectomized rats was observed even 8 weeks after the operation (Table 3), suggesting that uremia was not severe in these animals. Latamoxef slightly decreased the aggregation at a higher dose (Tables 4 and 5). This inhibition also seems to be related to the drug concentration in blood, but is inconsistent with our experimental results. Bang et al. (4) previously demonstrated that latamoxef treatment decreases ADP-induced platelet aggregation in human volunteers. This decrease is dosedependent; daily treatment with $12 \mathrm{~g}$ or $6 \mathrm{~g}$ of latamoxef for one week decreased the aggregation but that with $3 \mathrm{~g}$ did not. The mechanism of this inhibition is not known. Many beta-lactam antibiotics, including carbenicillin, latamoxef and cefotaxime, inhibit ADP-induced platelet aggregation in vitro but at extremely high concentrations like $1000 \mu \mathrm{g} / \mathrm{ml}$ or more (4). It is not yet known whether the in vivo inhibition occurs by the same mechanism as in the in vitro type, but if it is the same, the drug concentration in the blood may be related to the manifestation of the in vivo inhibition of platelet aggregation. NMTT does not inhibit rat platelet aggregation either in vivo or in vitro at a final concentration of $10 \mathrm{mM}$ (K. Uchida and T. Ishigami, unpublished data). Therefore, the inhibition of platelet function may be related to the beta-lactam ring or surrounding structures.

Acknowledgements: We express our sincere thanks to Dr. Nils U. Bang for his valuable discussions and review of this paper. We also sincerely thank. Drs. K. Sugeno and T. Yoshizaki for the pharmacokinetic analysis of latamoxef and measurement of plasma concentrations of creatinine, urea nitrogen and proteins. We thank Messrs. H. Kakushi, T. Shike and $T$. Shimizu for their help with the experiments. We also thank Miss $M$. Katayama for preparing the manuscript.

\section{References}

1 Hochman, R., Clark, J., Rolla, A., Thomas, S., Kaldany, A. and D'Elia, J.A.: Bleeding in patients with infections: Antibiotics helping or hurting? (editorial) Arch. Intern. Med. 142, 1440-1442 (1982)

2 Andrassy, K., Koderisch, J., Fritz, S. and Ritz, E.: New beta-lactam antibiotics and hemorrhagic diathesis: Comparison of moxalactam and 
cefotaxime. Clin. Ther. 6, 34-42 (1983)

3 Reddy, J. and Baily, R.R.: Vitamin $K$ deficiency developing in patients with renal failure treated with cephalosporin antibiotics. New Zealand Med. J. 672, 378-379 (1980)

4 Bang, N.U., Tessler, S.S., Heidenreich, R.O., Marks, C.A. and Mattler, L.E.: Effects of moxalactam on blood coagulation and platelet function. Rev. Infect. Dis. 4, S546-S554 (1982)

5 Weitekamp, R.M. and Aber, R.C.: Prolonged bleeding times and bleeding diathesis associated with moxalactam administration. JAMA 249 , 69-71 (1983)

6 Pakter, R.L., Russell, T.R., Mielke, C.M. and West, D.: Coagulopathy associated with the use of moxalactam. JAMA 248, 1100 (1982)

7 Lipsky, J.J., Lewis, J.C. and Nvick, W.J., Jr.: Production of hypoprothrombinemia by moxalactam and 1-methyl-5-thiotetrazole in rats. Antimicrob. Agents Chemother. 25, 380-381 (1984)

8 Uchida, K., Ishigami, T., Matsubara, T. and Narisada, M.: Effects of $N$-methyltetrazolethiol (NMTT) and NMTT containing antibiotics on gamma-glutamylcarboxylation. The 24th Interscience Conference on Antimicrobial Agents and Chemotherapy. Washington D.C., Abstract. p. 289 (1984)

9 Rymer, W. and Greenlaw, C.W.: Hypoprothrombinemia associated with cefamandol. Drug Intell. Clin. Pharm. 14, 780-783 (1980)

10 Hooper, C.A., Haney, B.B. and Stone, H.H.: Gastrointestinal bleeding due to vitamin $K$ deficiency in patients on parenteral cefamandole. Lancet i, 39-40 (1980)

11 Carlberg, H., Alestig, K., Nord, C.E. and Trollfors, B.: Intestinal side effect of cefoperazone. J. Antimicrob. Chemother. 10, 483-487 (1982)

12 Barriere, S.L. and Flaherty, J.F.: Thirdgeneration cephalosporins: a critical evaluation. Clin. Pharm. 3, 351-373 (1984)

13 Shimada, K., Matsuda, T., Inamatsu, T. and Urayama, K.: Bleeding secondary to vitamin $K$ deficiency in patient receiving parenteral cephem antibiotics. J. Antimicrob. Agents Chemother. 14, Supp. B, 325-330 (1984)

14 Wise, R. and Dent, J.: Stability of beta-lactam antibiotics containing $N$-methylthiotetrazale side-chain. Lancet ii, 624-625 (1983)

15 Uotila, L. and Suttie, J.W.: Inhibition of vitamin $K$-dependent carboxylase in vitro by cefamandole and its structural analogues. J. Infect. Dis. 148, $571-578$ (1983)

16 Kerremans, A.L., Lipsky, J.J., Van Loon, J.,
Gallego, M.O. and Weinshiboum, R.M.: Cephalosporin-induced hypoprothrombinemia: possible role for thiol methylation of 1 -methyltetrazole-5-thiol and 2-methyl-1,3,4-thiadiazole5-thiol. J. Pharmacol. Exp. Ther. 235, 382-388 (1985)

17 Suttie, J.W., Engelke, J.A. and McTigne, J.: Effect of $N$-methylthiotetrazole on rat liver microsomal vitamin $\mathrm{K}$-dependent carboxylation. Biochem. Pharmacol. 35, 2429-2433 (1986)

18 Ormrod, D. and Miller, T.: Experimental uremia. Description of a model producing varying degrees of stable uremia. Nephron 26, 249-254 (1980)

19 Chasson, A.L., Grady, H.J. and Stanley, M.A.: Determination of creatinine by means of automatic chemical analysis. Am. J. Clin. Pathol. 35, 83-88 (1961)

20 Born, G.V.R.: Aggregation of blood platelets by adenosine diphosphate and its reversal. Nature 194, 927-929 (1962)

21 Uchida, K., Nomura, Y., Takase, H., Harauchi, T., Yoshizaki, T. and Nakao, H.: Effects of vitamin K-deficient diets and fasting on blood coagulation factors in conventional and germ-free rats. Japan. J. Pharmacol. 40, 115-122 (1986)

22 Suttie. J.W.: Vitamin K-dependent carboxylase. Annu. Rev. Biochem. 54, 459-477 (1985)

23 Lipsky, J.J.: N-Methy-thio-tetrazole inhibition of the gammacarboxylation of glutamic acid: Possible mechanism for antibiotic-associated hypoprothrombinaemia. Lancet ii, 192-193 (1983)

24 Uchida, K., Ishigami, T. and Komeno, T.: Effects of latamoxef and methyltetrazolethio on gammaglutamylcarboxylase activity. Japan. J. Pharmacol. 35, 330-333 (1984)

25 Bechtold, H., Lorenz, J., Weilmann, L.S., Meinertz, T., Trenk, D., Andrassy, K. and Jähnchen, E.: Possible coumarin-like mechanism of action for cephalosporins. Klin. Wochenschr. 62, 885-886 (1984)

26 Bechtold, H., Andrassy, K., Jähnchen, E., Koderisch, J., Koderisch, H., Weilmann, L.S., Sonntag. H.-G. and Ritz, E.: Evidence for impaired hepatic vitamin $K_{1}$ metabolism in patients treated with $N$-methylthiotetrazole cephalosporins. Thromb. Haemostas. 51, 358361 (1984)

27 Barckow, D. and Schwigon, C.D.: Unterschungen zu Therapie und Prophylaxe moxalactaminduzierter Hypoprothrombinämien bei Intensivpatienten. Intensivmed. Prax. 22, 233-237 (1985)

28 Fainstein, V., Bodey, G.P., McCredie, K.B., 
Keating, M.J., Estey, E.H., Bolivar, R. and Elting, L.: Coagulation abnormalities induced by beta-lactam antibiotics in cancer patients. $J$. Infect. Dis. 148, 745-750 (1983)

29 Bang, N.U., Trygstad, C.W., Schroeder, J.E., Heidenreich, R.O. and Csiscko, B.M.: Enhanced platelet function in glomerular renal disease. J. Lab. Clin. Med. 81, 651-660 (1973)

30 Yoshida, N. and Aoki, N.: Release of arachidonic acid from human platelets. A key role for the potentiation of platelet aggregability in normal subjects as well as in those with nephrotic syndrome. Blood 52, 969-977 (1978)

31 Rabiner, S.F. and Molians, F.: The role of phenol and phenolic acid on the thrombocytopathy and detective platelet aggregation of patients with rena! failure. Am. J. Med. 49, 346-351 (1970) 